\title{
The Transcriptional Regulatory Network of Corynebacterium pseudotuberculosis
}

\author{
Doglas Parise ${ }^{1,2, *,+}+$ C, Mariana Teixeira Dornelles Parise ${ }^{1,2, \dagger}$, Anne Cybelle Pinto Gomide ${ }^{2}$, \\ Flávia Figueira Aburjaile ${ }^{3}{ }^{-}$, Rodrigo Bentes Kato ${ }^{2}\left(\mathbb{D}\right.$, Marisol Salgado-Albarrán ${ }^{1,4}$, Andreas Tauch 5 ,
} Vasco Ariston de Carvalho Azevedo ${ }^{2, \ddagger}$ and Jan Baumbach $1,6,7, \neq$

Citation: Parise, D.; Teixeira Dornelles Parise, M.; Pinto Gomide, A.C.; Figueira Aburjaile, F.; Bentes Kato, R.; Salgado-Albarrán, M.; Tauch, A.; Ariston de Carvalho Azevedo, V.; Baumbach, J. The Transcriptional Regulatory Network of Corynebacterium pseudotuberculosis. Microorganisms 2021, 9, 415. https://doi.org/10.3390/ microorganisms 9020415

Academic Editor: Anthony J. Sinskey

Received: 5 February 2021

Accepted: 14 February 2021

Published: 17 February 2021

Publisher's Note: MDPI stays neutral with regard to jurisdictional claims in published maps and institutional affiliations.

Copyright: (c) 2021 by the authors. Licensee MDPI, Basel, Switzerland. This article is an open access article distributed under the terms and conditions of the Creative Commons Attribution (CC BY) license (https:// creativecommons.org/licenses/by/ $4.0 /)$.
1 Chair of Experimental Bioinformatics, TUM School of Life Sciences, Technical University of Munich, 85354 Freising-Weihenstephan, Germany; mparise@wzw.tum.de (M.T.D.P.); marisol.salgado@tum.de (M.S.-A.); jan.baumbach@uni-hamburg.de (J.B.)

2 Institute of Biological Sciences, Universidade Federal de Minas Gerais, Belo Horizonte, Minas Gerais 31270-901, Brazil; acybelle@gmail.com (A.C.P.G.); rbkato@gmail.com (R.B.K.); vasco@icb.ufmg.br (V.A.d.C.A.)

3 Oswaldo Cruz Institute, Fiocruz, Rio de Janeiro, Rio de Janeiro 21040-360, Brazil; faburjaile@gmail.com

4 Departamento de Ciencias Naturales, Universidad Autónoma Metropolitana Cuajimalpa, Mexico City 05348, Mexico

5 Center for Biotechnology (CeBiTec), Bielefeld University, 33615 Bielefeld, Germany; tauch@cebitec.uni-bielefeld.de

6 Computational BioMedicine lab, Institute of Mathematics and Computer Science, University of Southern Denmark, 5230 Odense, Denmark

7 Chair of Computational Systems Biology, University of Hamburg, 22607 Hamburg, Germany

* Correspondence: dparise@wzw.tum.de or doglas@ufmg.br

+ These authors contributed equally to this study.

$\ddagger$ These authors share senior authorship.

\begin{abstract}
Corynebacterium pseudotuberculosis is a Gram-positive, facultative intracellular, pathogenic bacterium that infects several different hosts, yielding serious economic losses in livestock farming. It causes several diseases including oedematous skin disease (OSD) in buffaloes, ulcerative lymphangitis (UL) in horses, and caseous lymphadenitis (CLA) in sheep, goats and humans. Despite its economic and medical-veterinary importance, our understanding concerning this organism's transcriptional regulatory mechanisms is still limited. Here, we review the state of the art knowledge on transcriptional regulatory mechanisms of this pathogenic species, covering regulatory interactions mediated by two-component systems, transcription factors and sigma factors. Key transcriptional regulatory players involved in virulence and pathogenicity of C. pseudotuberculosis, such as the PhoPR system and DtxR, are in the focus of this review, as these regulators are promising targets for future vaccine design and drug development. We conclude that more experimental studies are needed to further understand the regulatory repertoire of this important zoonotic pathogen, and that regulators are promising targets for future vaccine design and drug development.
\end{abstract}

Keywords: Corynebacterium pseudotuberculosis; transcriptional regulatory mechanisms; transcription factors; two-component systems; sigma factors; virulence; pathogenicity

\section{Introduction}

Transcriptional regulation is one of the most important mechanisms of bacterial adaptation to changes in the environment; in particular, pathogenic bacteria use this mechanism to contend the conditions they are exposed to when infecting the host. These conditions are associated with immune barriers imposed by the host to fight the infection; for instance, $\mathrm{pH}$, oxidative and osmotic stresses, temperature and changes in nutrient availability. To quickly adapt, survive and establish the infection, transcriptional regulation controls key biological processes, such as biofilm formation, quorum sensing, temperature 
sensing and regulation of virulence, are key transcriptional elements of pathogens [1]. For a comprehensive review of bacterial gene regulation mechanisms in general see, for example, [2].

The main players in gene regulation are transcription factors (TFs), which are regulatory proteins that activate or repress the expression of their target genes (TGs) [3,4]. TF-TG relationships can be experimentally investigated using techniques such as RNA-Seq [5], expression microarrays [6], electrophoretic mobility shift assay (EMSA) [7,8], chromatin immunoprecipitation and DNA microarray (ChIP-chip) [9] and chromatin immunoprecipitation and sequencing (ChIP-seq) [10]. RNA-Seq and expression microarrays are used to measure the transcriptional profile of an organism under different conditions; for a comparison of these techniques see [11] and for comprehensive reviews see [12-15]. EMSA, ChIP-chip and ChIP-seq are used to identify transcription factor binding sites (TFBSs), which are the genomic regions occupied by TFs to regulate gene expression. For comprehensive reviews about ChiP-chip and ChiP-Seq see [16-18].

To have a broader view of these TF-TG relationships in systems biology, we model these as directed graphs in which the nodes represent the TFs or the TGs and the arcs, also called directed edges, represent the regulatory interactions, forming what is called transcriptional regulatory network (TRN) [3,4]. Data generated from both experimental and computational techniques are often available from online TRN databases such as RegulonDB [19] for Escherichia coli K12, Subtiwiki [20] for Bacillus subtilis, Abasy Atlas [21] for Corynebacterium glutamicum and CoryneRegNet [22] for the genus Corynebacterium. Such computational models have been utilized to understand the transcriptional mechanisms modulating cellular adaptation, survival and pathogenicity of several bacteria species $[23,24]$. For instance, several studies have demonstrated the role of TFs in the regulation of virulence in pathogenic bacteria such as Mycobacterium tuberculosis [25-29], Pseudomonas aeruginosa [30] and Helicobacter pylori [31]. Despite the experimental and computational advances, there are several understudied pathogenic bacteria that have no efficient treatment, amongst them we can highlight Corynebacterium pseudotuberculosis.

C. pseudotuberculosis is a pathogenic bacterium that stands out for being an organism of medical and veterinary importance that causes great economic impact on agriculture worldwide. This bacterium is a Gram-positive, facultative intracellular organism that is part of the order Corynebacteriales, which includes species of Corynebacterium, Mycobacterium, Nocardia and others. It is also classified into equi and ovis biovars, each causing different diseases [32]. The first causes ulcerative granulomatous lesions and mastitis in cattle [33,34], ulcerative lymphangitis (UL) or pigeon fever in horses [35] and oedematous skin disease (OSD) in buffaloes [36]. The second mainly affects small ruminants such as sheep and goats, as well as humans, causing caseous lymphadenitis (CLA) [37]. Furthermore, finding an effective vaccine against these bacteria is still a challenge [38,39]. Despite the importance of C. pseudotuberculosis, little is known about the mechanisms that control gene expression. A few studies have evaluated its transcriptional profile across different environmental conditions [40-43] and a few others have investigated mutant strains showing the importance of specific genes, such as $p l D$ [44], the fag $A B C$ operon [45] and phoP [46] in C. pseudotuberculosis virulence and pathogenicity. Recently, Parise et al. reconstructed in silico TRNs for all C. pseudotuberculosis strains with complete genome sequences and made it available in the seventh version of CoryneRegNet [22].

In this review, we collect, summarize and examine the current knowledge of transcriptional regulation of C. pseudotuberculosis. First, we present the TRNs and co-expression networks available for this organism. Then, we discuss single-gene studies and "omic" analyses together with the TRNs regarding the presented genes in order to understand the transcriptional regulation of C. pseudotuberculosis; these results are presented by distinct regulator types: two-component signal transduction systems (TCSs), TFs and sigma factors. In this way, we aim to summarize and condense our view on C. pseudotuberculosis transcriptional regulation by jointly discussing RNA-seq and mutation assays in the light of network biology. 


\section{Gene Co-Expression Networks and Transcriptional Regulatory Networks}

To understand how genes interact and influence the expression of other genes, TRNs and gene co-expression networks (GCNs) have been used to analyze bacterial genomes [19,20,47-49]. While TRNs present regulatory interactions between regulatory proteins and their targets, GCNs present correlation between the expression of certain genes in the network. Such networks have been used to model how regulatory processes work inside the cell, including amino acid synthesis and virulence mechanisms [50-53]. Franco et al. [54] and Parise et al. [22] performed GCN analysis and TRN transfer, respectively, in C. pseudotuberculosis.

Franco et al. inferred the GCNs of four C. pseudotuberculosis strains (258, T1, Cp13 and 1002) using RNA-Seq datasets [40-43]. The authors applied the following bioinformatic tools: (i) miRsig [55] to infer the GCNs of all genes and differentially expressed genes (DEGs), (ii) miRinfluence [56] to identify the predicted networks' influential and causal genes and (iii) Online GEne Essentiality (OGEE) database v2 [57] to classify the causal genes as essential, nonessential or conditionally essential [54]. Essential, nonessential and conditionally essential genes demonstrate the consensus of the level of essentiality of a certain gene for bacterial survival, for more details see [57]. The total number of genes and gene-gene interactions of each GCN are presented in Table 1. In the GCN analyses, the following genes were considered causal and categorized as essential: galU and $\arg S$ in 258; $p d p B$ and $\operatorname{trp} C$ in T1; and $\operatorname{ser} C, \operatorname{mraY}$ and $g \operatorname{lm} S$ in Cp13. The above-mentioned genes had not previously been analyzed experimentally in C. pseudotuberculosis; however, previous studies in other bacterial species support their relevance for organisms' growth and survival [58-63]. For instance, gall increases glycogen and trehalose amounts in C. glutamicum [58], and it is also a potential drug target in $M$. tuberculosis [59]. The $\arg S$ gene encodes an arginyl-tRNA synthetase [60], which is induced in the presence of arginine and repressed in the presence of lysine. A study has also proposed that the absence of argS is lethal for Brevibacterium lactofermentum, because it is not able to synthesize proteins without an arginyl-tRNA synthetase [64]. The $p d p B$ gene is homologous of the $l \mathrm{cmF}$ gene, which is the result of the fusion of the radical B12 enzyme isobutyryl-CoA mutase and its G-protein chaperone [61,65]. In Francisella, a deletion mutant of this gene is defective for intracellular bacterial growth [61]. The $\operatorname{trpC}$ gene, an indole-3-glycerol phosphate synthase [66], is considered essential for growth in both M. tuberculosis and Mycobacterium. bovis [67], and was identified as a potential drug target in $M$. tuberculosis [59]. The serC gene encodes a phosphoserine aminotransferase and is involved in the biosynthesis of L-serine in C. glutamicum [68]. In E. coli it is induced by cyclic AMP-dependent and together with aro $A$ encodes enzymes that lead serine and aromatic amino acids synthesis [69]. The $\operatorname{mar} Y$ gene encodes an undecaprenyl-phosphate phospho- $N$-acetylmuramoyl-pentapeptide transferase [70] and is considered essential for cell growth in E. coli [63]. It also participates in the building process of the peptidoglycan layer of the cell wall in corynebacteria [71]. The $\mathrm{glmS}$ gene is a glucosamine-6-phosphate synthase that can enhance $N$-acetylglucosamine synthesis in C. glutamicum [62] and was also indicated as a drug target in M. tuberculosis in $[72,73]$.

Table 1. Gene co-expression network (GCN) data from Franco et al. [54]. DEGs -differentially expressed genes.

\begin{tabular}{ccccccc}
\hline \multirow{2}{*}{ Strain } & \multirow{2}{*}{ Technology } & \multicolumn{2}{c}{ GCN from All Genes } & \multicolumn{2}{c}{ GCN from DEGs } & \multirow{2}{*}{ Reference } \\
\cline { 3 - 6 } & & Genes & Interactions & Genes & Interactions & \\
\hline Cp13 & Ion Proton & 2113 & 86,367 & 63 & 46 & {$[43]$} \\
\hline T1 & Ion Proton & 2093 & 107,202 & 93 & 98 & {$[43]$} \\
\hline 1002 & SOLiD & 2091 & 6682 & 168 & 155 & {$[40]$} \\
\hline 258 & SOLiD & 2064 & 9376 & 139 & 165 & {$[41,42]$} \\
\hline
\end{tabular}


Parise et al. analyzed the conservation of transcriptional regulation in the genus Corynebacterium [22]. The authors used experimental TRNs of $M$. tuberculosis, B. subtilis, C. glutamicum and E. coli as models for predicting the TRNs of all complete genomes of this genus, including 91 strains from C. pseudotuberculosis. This prediction was performed by checking the conservation of the TFs and the TGs with BLAST software [74] and the conservation of the TFBSs with HMMER package [75]. These predictions are publicly available in CoryneRegNet 7, which holds 24,069 regulatory interactions, 2990 TFs and 17,298 TFBSs for this species. Such networks will be discussed and presented alongside literature data regarding C. pseudotuberculosis regulations in the following sections.

\section{Regulators of Gene Expression}

\subsection{Two-Component Systems}

Two-component signal transduction systems (TCS) detect and mediate the response to external stimuli by means of a series of biochemical signals that result in gene expression changes $[46,76]$. These processes regulate many processes such as drug resistance, adhesion, sporulation, pilus formation, cell division, nutrient acquisition, nitrogen fixation and virulence [77-80].

One of the most well-known TCS is the PhoPR system, in which a transmembrane sensory histidine kinase protein (PhoR) phosphorylates the receiver domain of the response regulator protein (PhoP). The phosphorylation of PhoP results in the activation of the effector domains, which causes a transcriptional response. Some studies have used phoP mutant strains as vaccinal strategies, not only in C. pseudotuberculosis, but also in M. tuberculosis $[46,81]$. In C. pseudotuberculosis, these mutant strains presented reduced virulence in mice and induced a host cellular immune response [46]. Additionally, the absence of the phoP gene resulted in higher levels of IgG antibodies in contrast with the control group.

In CoryneRegNet 7 [22], the predicted TRN of the phoP and phoR genes in C. pseudotuberculosis 1002B strain is shown in Figure 1 . The TFs $p h o P$ and $g l x R$ jointly activate the phosphate ATP-binding cassette (ABC) transporters pstB, pstC, pstS and Cp1002B_RS04420 (frameshift $p s t A$ ). The $p p i B$ gene is repressed by $p h o P$ and is dually regulated by $g l x R$, while phoR is activated by phoP. Due to its crucial role in bacterial survival, development and adaptation to environmental changes, the PhoPR system is an interesting drug target for future studies [46,82]. In C. glutamicum, the pstSCAB operon, an ABC transport system for the uptake of phosphate, is induced during phosphate starvation [83]. The ppiB gene is a peptidyl-prolyl cis/trans isomerase (PPIase); it is important for growth in both low temperatures and starvation conditions in Legionella pneumophila [84] and B. subtilis [85]. PPIases were marked as alternative drug targets [86]. Both the pstSCAB operon and the PPIases were already indicated as bacterial virulence factors in L. pneumophila [86] and Salmonella [87-89].

The hrrA gene is part of the HrrSA TCS and it was differentially expressed in both C. pseudotuberculosis $\mathrm{T} 1$ and $\mathrm{CP} 13$ under iron starvation [43]. This system both activates the expression of a heme oxygenase ( $h m u O$ gene) and represses genes acting in heme homeostasis in C. glutamicum and Corynebacterium diphtheriae [91,92], and is considered the global regulator of heme in C. glutamicum [93]. In this system the HrrS is the sensor kinase and the HrrA is the response regulator. Furthermore, Franco et al. [54] identified three TCS genes, namely, tcs $S 4, m p r A \_2$ and $t c s R 3$, as influential genes. However, they remain to be studied; there is no regulatory information in CoryneRegNet 7 for the HrrSA TCS and the three genes found by Franco et al. 


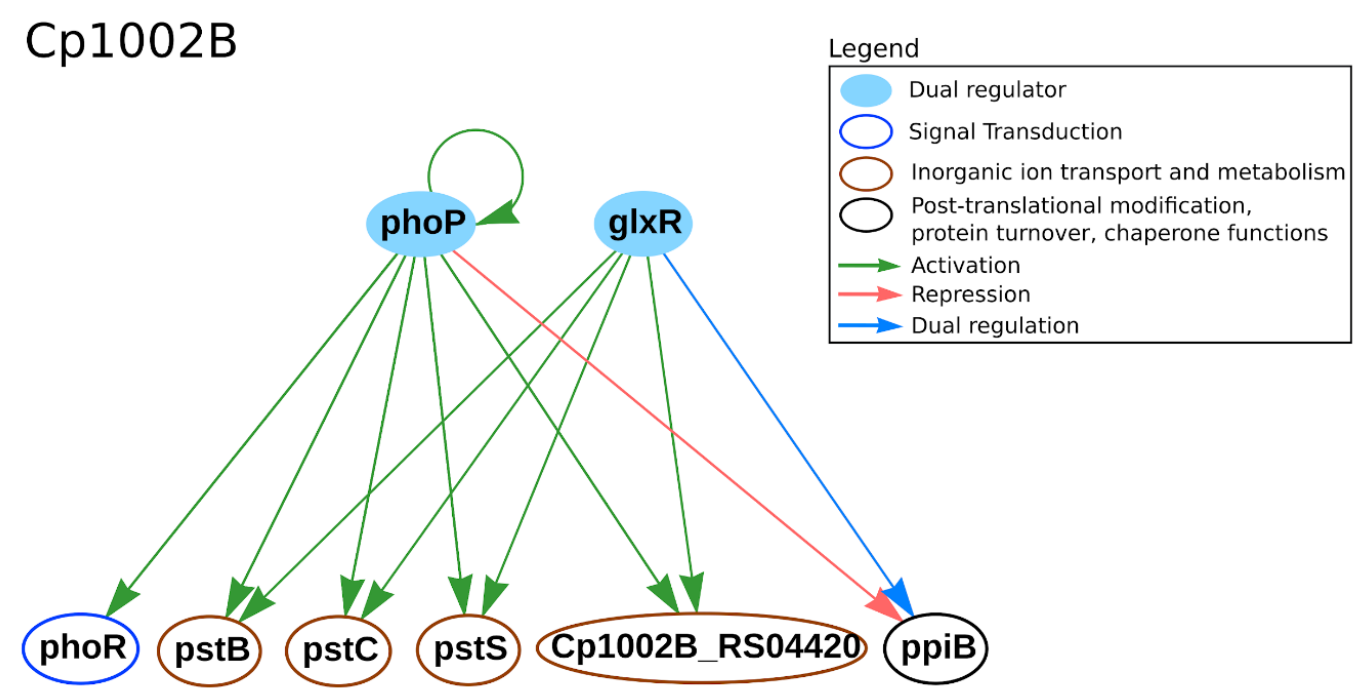

Figure 1. PhoPR transcriptional regulatory network (TRN) retrieved from CoryneRegNet 7 [22] for C. pseudotuberculosis 1002B. In the network, nodes represent the genes and arrows represent the regulatory interactions. The functional classification was performed using the database Eggnog (evolutionary genealogy of genes: non-supervised orthologous groups) [90].

\subsection{Transcription Factors}

TFs can modulate gene expression through activating or repressing transcription by different mechanisms. In all mechanisms, activation enhances the interaction between the RNA polymerase and the promoter, and repression prevents their interaction [94]. In bacteria, the environmental signals are the elements responsible to modulate TFs activity influencing transcription initiation [95]. In this section we describe the TFs that perform key functions in C. pseudotuberculosis in the context of the biological mechanism they are involved in.

\subsection{Metalloregulation: Iron Uptake}

Metal ions are essential for bacterial metabolism; in particular, iron, manganese and zinc are used as cofactors [96]. Iron is an important protein cofactor required for growth and development in virtually all living organisms; the acquisition of host iron is a well-characterized mechanism of infections used by bacterial pathogens to successfully establish the infection in host cells. Besides its importance, an excess of iron can be toxic to the cell; thus, in order to keep iron homeostasis, bacteria developed a tightly-regulated system $[43,97]$.

A recent study used RNA-Seq to analyze C. pseudotuberculosis-infected spleens of dairy goats and found many iron-related genes differentially expressed in order to reduce iron availability. The authors hypothesized that C. pseudotuberculosis evolved an iron acquisition mechanism to manage this reduction [98]. The expression of DtxR, the master regulator of iron, is downregulated under iron limitation, directly and indirectly influencing the expression of several genes in C. pseudotuberculosis [43]. In CoryneRegNet, this TF is predicted to regulate sixteen genes in both Cp13 and CpT1 [22]; such regulatory interactions are presented in Figures 2 and 3, respectively. Some of DtxR's target genes are the $f a g A B C$ operon and the $f a g D$ gene, which are components of the iron acquisition system and important virulence factors of this organism [40,45]. Studies in C. diphtheriae and C. pseudotuberculosis indicate that DtxR regulates the ciuA gene $[99,100]$; however, a recent study [43] in C. pseudotuberculosis T1 and Cp13 found no difference in the expression of these genes under iron restricted conditions. Likewise, DtxR is not predicted to regulate the gene $\operatorname{ciuA}$ in CoryneRegNet [22]. The authors of the iron-limitation study [43] used the Ion Proton platform to analyze the transcriptome of the wild-type C. pseudotuberculosis strain $\mathrm{T} 1$ and its mutant strain, Cp13, which has a disrupted ciuA gene. The ciuA 
gene encodes a protein highly similar to siderophore ABC-type transport systems and has been previously associated with virulence [101]. The lack of this gene resulted in reduced growth [43] and intracellular viability [102] of the mutated strain. In the same study, 77 and 59 DEGs were identified in T1 and Cp13, respectively. Besides that, the authors observed an up-regulation of hemin acquisition systems and down-regulation of iron intracellular utilization in both strains. The expression of hemin uptake systems in Cp13 may indicate the adaptive response of the transcription machinery to iron acquisition from other sources. Hemin uptake genes were found in genomic islands together with many known virulence factors, corroborating previous studies pointing to the association of iron uptake and virulence in C. pseudotuberculosis [43,45,102].

\section{CpT1}

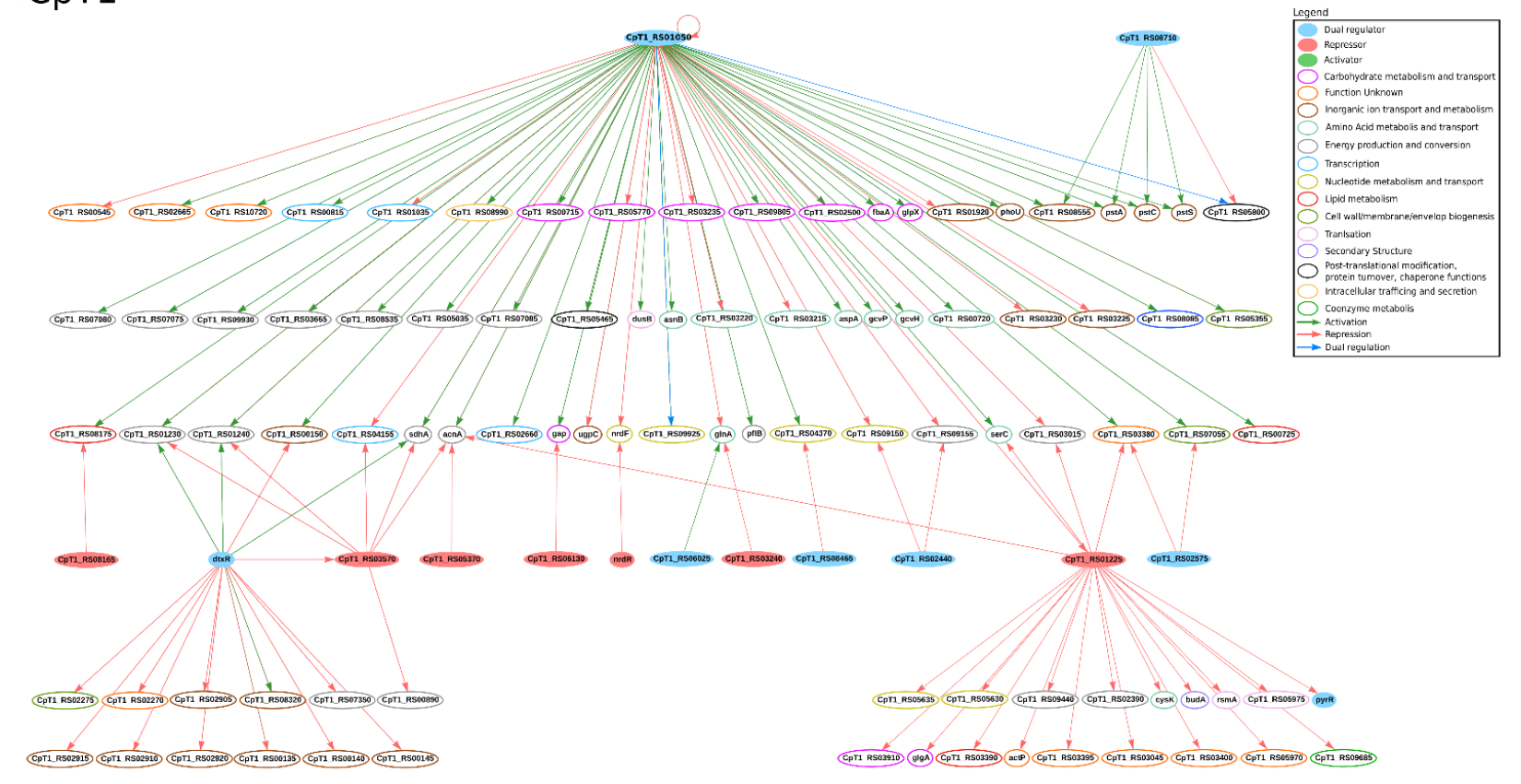

Figure 2. Regulatory interactions taken from CoryneRegNet 7 [22] for C. pseudotuberculosis T1 under iron limitation in [43]. In the network, nodes represent the genes and arrows represent the regulatory interactions. The functional classification was performed using the database Eggnog [90].

In the same study, iron restriction increased the expression of genes associated with putative hemin acquisition systems and decreased the expression of genes associated with energy metabolism in both strains. Down-regulated genes involved in the oxidative phosphorylation process and tricarboxylic acid cycle (TCA) cycle were only found in the T1 strain. Amongst them, $s d h A, s d h B$ and $s d h C$ genes encode succinate dehydrogenase ironsulfur proteins, which compose the respiratory complex II. In this complex, the succinate reduction links the oxidative phosphorylation process with the TCA. These genes are predicted to be jointly regulated by GlxR, DtxR and RipA. Regarding the TFs, Ibraim and collaborators [43] found the following up-regulated genes: ripA in both strains; $g l p R$, $\operatorname{csp} A$, whiB and sufR in Cp13; and $g l x R$ in T1. In CoryneRegNet, only rip $A$ and $g l x R$ regulate other genes in these strains [22]. Rip $A$ encodes a protein that belongs to the AraC family regulators that repress the expression of genes encoding iron-containing proteins. This TF is predicted to be regulated by DtxR and to regulate six genes in both $\mathrm{T} 1$ and Cp13 in [22]; the $s d h A, s d h B$ and $s d h C$ genes were identified as differentially expressed in the iron limitation assay [43]. GlxR is a global regulator involved in the regulation of metabolic processes [91,92]. It is predicted to regulate 79 genes in both T1 and Cp13 [22], including two TFs: ramB homologue (CpCp13_RS01220 and CpT1_RS01225) and whiB homologue (CpCp13_RS01035, CpCp13_RS02650 and CpT1_RS02660) in both strains. The predicted regulatory networks of the DEGs found under iron limitation in T1 and Cp13 
are presented in Figures 2 and 3, respectively [22]. The regulators RamB, TetR family protein (CpT1_RS08165), AcnR homologue (CpT1_RS05370), NrdR, AmtR homologue (CpT1_RS03240), RamA homologue (CpT1_RS08465), RbsR homologue (CpT1_RS02440), MtrA homologue (CpT1_RS02575) and PyrR are present in the regulatory network and were not identified in the experimental assays, which indicated that they may be involved in other cellular functions other than metalloregulation and need to be further investigated.

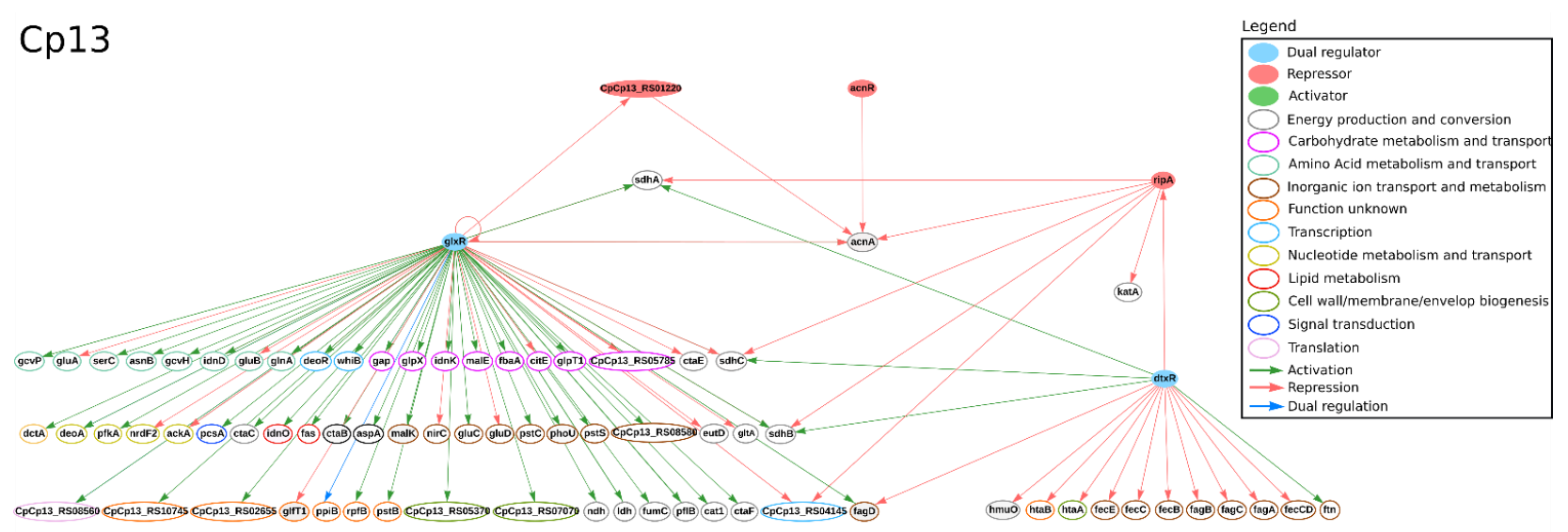

Figure 3. Regulatory interactions taken from CoryneRegNet 7 [22] for C. pseudotuberculosis Cp13 under iron limitation in [43]. In the network, nodes represent the genes and arrows represent the regulatory interactions. The functional classification was performed using the database Eggnog [90].

\subsection{Response to Osmotic, Thermal and Acid Stress}

Bacteria experience stress conditions not only when migrating from the environment to the host, but also when invading and colonizing the host's bloodstream, gastrointestinal and respiratory tracts, mucous membranes and immune system [103-105]. In order to survive these conditions, the organism must assemble a quick protective response at the transcriptional level $[105,106]$. During environmental changes, a reduction, or even a lack of growth, is considered normal in bacteria $[40,107]$. Three studies in C. pseudotuberculosis point out a reduction of replication of $\sim 23 \%, \sim 27 \%$ and $\sim 34 \%$ in strain 1002 and 16\%, 20\% and $36 \%$ in strain 258 under osmotic, thermal and acid stresses, respectively [40-42]. The first study performed a differential expression analysis under these conditions in C. pseudotuberculosis 1002 and identified DEGs involved in oxidoreduction, adhesion and cell division processes [40]. The other two allow us to further understand the transcriptional response induced during these stresses in C. pseudotuberculosis 258 [41,42]. In all three studies, the authors performed transcriptome analyses using the SOLiD 3 Plus platform [40-42]. A notable TF identified in these two strains is TetR2, a DEG found across the three stress conditions. This TF belongs to the TetR family that in general regulates the expression of genes involved in drug resistance, biosynthesis of antibiotics, pathogenicity, virulence, quorum sensing and catabolic pathways [40-42,108]. So far, there is no experimentally verified or predicted regulation for this TF in C. pseudotuberculosis 1002B and 258.

Under acid stress the following DEGs were highly expressed: $m s r B$ in strain 1002B, $m s r A$ in strain 258 and both $d p s$ and lysR1 in these two strains [40,42]. In CoryneRegNet, the TF LysR1 is predicted to repress itself and activates the expression of the peroxiredoxin gene $\operatorname{ahpC}$ in both strains. Gomide et. al. 2018 suggests that this TF plays a modulatory role in C. pseudotuberculosis 258; however, no experimentally verified LysR1 regulation is known in these strains [42]. In P. aeruginosa, a LysR-family TF regulates the expression of genes related to virulence and stress response modulators [109]. The $m s r B$ and $m s r A$ gene products act together resulting in the catalytic activity of the oxidation-reduction of methionine sulfoxide. The $m s r A$ gene plays a more relevant role in virulence than $m s r B$ does in bacteria $[42,110]$; it corroborates the fact that C. pseudotuberculosis strains from the equi biovar, such as 258, are more virulent than the ones from the ovis biovar, such as 1002B. 
The $d p s$ gene protects the bacteria under acid, oxidative and heat stresses, as well as in iron and copper toxicity. The inactivation of this gene in $E$. coli leads to a reduction in the survival rate of the bacteria in an acid environment $[42,111,112]$. The $d p s, m s r A$ and $m s r B$ genes have no regulatory interactions predicted in CoryneRegNet [22] and are interesting candidates for future experimental assays.

Under thermal shock stress, $h s p R, d n a K$ and $g r p E$ genes were differentially expressed in both organisms. The $h s p R$ gene, which encodes a heat shock TF, is known for regulating genes involved in virulence and pathogenicity $[40,113]$. Additionally, it regulates heat shock operons, which encode genes that maintain the structure of proteins in several cell stresses [114,115]. Likewise, in 1002B and 258 it is predicted to regulate four genes: $d n a K$, $g r p E, \operatorname{clpB}$ and $\operatorname{clgR}$. The $d n a K$ gene improves the immune response in the host and seems to regulate genes encoding virulence factors and bacterial adhesion $[40,115]$. The grpE gene is also a chaperone involved in bacterial virulence and belongs to the same operon as $h s p R$ and $d n a K$ [41]. The $c l p B$ gene was differentially expressed under both thermal and osmotic stresses in the strain 258. It encodes an ATP-dependent chaperone that is involved in virulence and participates in the stress response system [116,117]. The $\operatorname{clg} R$ gene regulates the expression of genes acting in DNA repair and proteolysis in C. glutamicum [118]. In CoryneRegNet, it is predicted to regulate seven genes in C. pseudotuberculosis $1002 \mathrm{~B}$ and 258, as presented in Figure 4.

\section{Cp1002B / Cp258}

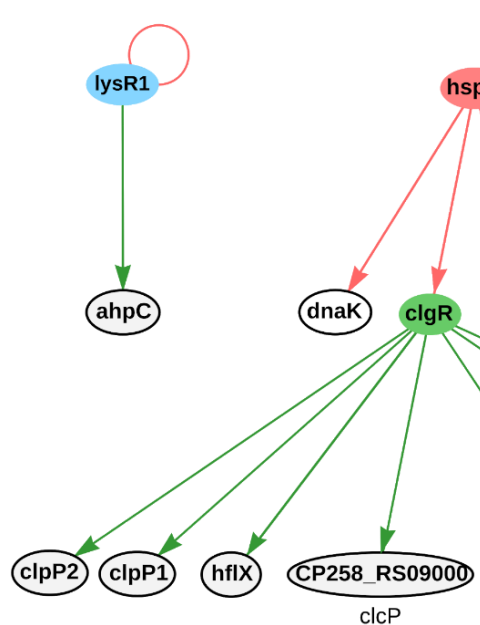

Legend
Dual regulator
Repressor
Activator
Energy production and conversion
Post-translational modification,
protein turnover, chaperone functions
Function unknown
$\longrightarrow$ Activation
$\longrightarrow$ Repression
$\longrightarrow$ Dual regulation

Figure 4. Regulatory interactions from CoryneRegNet 7 for the DEGs of C. pseudotuberculosis 258 (Cp1002B) and 1002B (Cp258) under osmotic, acid and heat stress conditions [41,42]. In the network, nodes represent the genes and arrows represent the regulatory interactions. The functional classification was performed using the database Eggnog [90].

Under osmotic stress the following DEGs were highly expressed: glmU and uppP in strain 258 and norM in strains 1002B and 258 [40,42]. The glmU gene encodes an enzyme that catalyzes the substrate in the synthesis of bacterial peptidoglycans and lipopolysaccharides of the cell wall [119]; it is predicted to be regulated by the glk homologue (CP258_RS07175) in C. pseudotuberculosis 258 in CoryneRegNet [22]. A study in Mycobacterium smegmatis showed that $g l m U$ is both a drug target and crucial for bacterial replication [120]. The uppP gene encodes an enzyme that is involved in the biosynthesis of both membrane proteins and bacterial cell wall components, a process that is essential for bacterial integrity [121,122]. This also makes the $u p p P$ gene crucial to bacterial growth and bacterial pathogenicity, making it an interesting drug and vaccine target, as well $[42,120]$. The norM gene is a multidrug efflux pump that belongs to an ABC transporter family, conferring organisms an effective antibiotic resistance $[42,123,124]$. In $C$. pseudotuberculosis 258 , the srt $A$ gene was differentially expressed under both osmotic and thermal stresses. The $s r t A$ gene encodes a sortase, which is a housekeeping gene involved in the pathogenesis and virulence of 
Gram-positive bacteria. It contributes to the covalent binding of the peptidoglycan layer and cell surface proteins $[41,42,125,126]$. There are no regulatory interactions for $u p p P$, norM and srtA genes in CoryneRegNet [22] for these strains, such genes are promising candidates for experimental assays. Figure 4 presents the regulatory interactions from CoryneRegNet of the genes found as DEGs in C. pseudotuberculosis 258 and 1002B (Figure 4) strains under osmotic, acid and heat stress conditions [40-42].

\subsection{Sigma Factors}

In prokaryotes, one of the most important stages of the gene expression regulation is the initiation of the transcription. During this stage, sigma factors are both required to assemble the RNA polymerase holoenzyme and to recognize the promoters $[127,128]$. Similar to TFs, sigma factors are key players in transcriptional regulation when adapting to stress conditions, such as osmotic, thermal, acid and nutrient starvation stresses $[129,130]$. These molecules are also known to be involved in the regulation of virulence genes [131,132]. Bacterial sigma factors include SigA, SigB, which are essential and nonessential, respectively, and the alternative sigma factors $\mathrm{SigC}$, SigD, SigE, SigH, SigK and SigM. These alternative sigma factors may belong to the extracytoplasmic factors group [133,134], which is responsible for the regulation of genes involved in the transport, cellular wall adaptation or secretion within the periplasm (Gram-negatives) or extracellular environment [131].

In C. pseudotuberculosis 1002 there are eight genes encoding sigma factors [135], whereas in C. glutamicum, a nonpathogenic bacteria, there are seven sigma factors [134]. In particular, the sigK gene is present only in C. pseudotuberculosis, which suggests that it may have a role in the virulence mechanisms of $C$. pseudotuberculosis. The study of Pinto et al. [40] observed the expression changes of some sigma factors in C. pseudotuberculosis 1002 in the beginning of the exponential phase under heat, osmotic and acid stresses, simulating host-infection conditions. The sigma factors analyzed in the aforementioned study are shown in Table 2.

Table 2. Fold-change values of the genes encoding sigma factors in osmotic $(2 \mathrm{M})$, heat $\left(50^{\circ} \mathrm{C}\right)$ and acid stresses $(\mathrm{pH})$, from Pinto et al. [40]. ${ }^{\circ} \mathrm{C}$-degree Celsius. ECF-Extracytoplasmic function.

\begin{tabular}{|c|c|c|c|c|c|c|c|}
\hline \multirow{2}{*}{$\begin{array}{l}\text { Sigma } \\
\text { Factor }\end{array}$} & \multirow[b]{2}{*}{ Product } & \multicolumn{2}{|c|}{ Osmotic Stress } & \multicolumn{2}{|c|}{ Thermic Stress } & \multicolumn{2}{|c|}{ Acid Stress } \\
\hline & & $\begin{array}{l}\text { Fold- } \\
\text { Change }\end{array}$ & DEG & $\begin{array}{l}\text { Fold- } \\
\text { Change }\end{array}$ & DEG & $\begin{array}{l}\text { Fold- } \\
\text { Change }\end{array}$ & DEG \\
\hline $\operatorname{sig} A$ & $\begin{array}{c}\text { RNA polymerase sigma factor SigA (essential } \\
\text { housekeeping sigma factor) }\end{array}$ & 2.1889 & Yes & 1.4903 & No & 0.9232 & No \\
\hline $\operatorname{sig} B$ & $\begin{array}{l}\text { RNA polymerase sigma factor SigB (non-essential } \\
\text { SigA-like) }\end{array}$ & 0.6348 & No & 0.9044 & No & 2.9154 & Yes \\
\hline $\operatorname{sigC}$ & RNA polymerase sigma factor SigC (ECF family) & 0.4675 & No & 0.8031 & No & 1.7238 & No \\
\hline $\operatorname{sig} D$ & RNA polymerase sigma factor SigD (ECF family) & 1.5437 & No & 1.2891 & No & 0.8654 & No \\
\hline $\operatorname{sig} E$ & RNA polymerase sigma factor SigE (ECF family) & 0.5483 & No & 0.9356 & No & 2.5244 & Yes \\
\hline $\operatorname{sigH}$ & RNA polymerase sigma factor SigH (ECF family) & 1.8401 & No & 1.7864 & No & 3.5832 & Yes \\
\hline $\operatorname{sigK}$ & RNA polymerase sigma factor SigK (ECF family) & 1.5887 & No & 1.7415 & No & 1.6199 & No \\
\hline $\operatorname{sig} M$ & RNA polymerase sigma factor SigM (ECF family) & 4.7414 & Yes & 3.5593 & Yes & 4.4934 & Yes \\
\hline
\end{tabular}

Considering the authors' fold-change threshold of $2 \times$, the following sigma factors were differentially expressed: $\operatorname{sig} A$ under osmotic stress; $\operatorname{sig} B$, sigE and $\operatorname{sig} H$ under acid stress; and sig $M$ in all conditions. In C. pseudotuberculosis 1002, the sig $A$ and sigH genes, which encode RpoD and RpoE sigma factors, respectively, were significantly differentially expressed in all three conditions. The sig $A$ gene, also known as sigma 70 , promotes the binding of the RNA polymerase to specific sites activating the transcription of most essential genes related to the exponential growth in E. coli [136]. In C. pseudotuberculosis 1002, this 
protein conserves the four domains belonging to sigma 70 . The $\operatorname{sig} B$ gene was considered to be induced in the same study and is known to regulate genes involved in the stress response of many Gram-positive bacteria. Both $\operatorname{sig} A$ and $\operatorname{sig} B$ were previously associated with virulence in other bacteria; SigA can be specifically required for the expression of virulence genes in M. tuberculosis [131,137]. SigB controls the expression of many genes involved in the virulence of pathogens, such as biofilm formation, cellular differentiation, pathogenesis, stress resistance and sporulation in several bacteria [131,138]. Pacheco et al. assessed the role of SigE in C. pseudotuberculosis using a sigE-mutant strain under different stress conditions, including acid stress. The authors observed a higher in vitro susceptibility of this bacteria in the host-simulated conditions, inferring the importance of SigE in the bacterial maintenance within the unfavorable environment [139].

Interestingly, no significant expression changes in these molecules were observed in both 258, under the same three stress conditions applied to C. pseudotuberculosis, and Cp13 and T1, under iron starvation [41-43]. For all sigma factor coding genes, it is necessary to unravel the regulon, as well as unveil all the interaction network coding genes of the sigma factors for a better understanding of the infection process and response modulation in the cell. The predicted regulatory interactions in CoryneRegNet of the sigma factors mentioned in this section are presented in Figure 5A,B for strains 1002B and 258, respectively. Finally, the function of experimentally studied sigma factors in C. glutamicum and M. tuberculosis help to provide clues on their regulatory roles in C. pseudotuberculosis $[133,136]$.

\section{A Cp1002B}
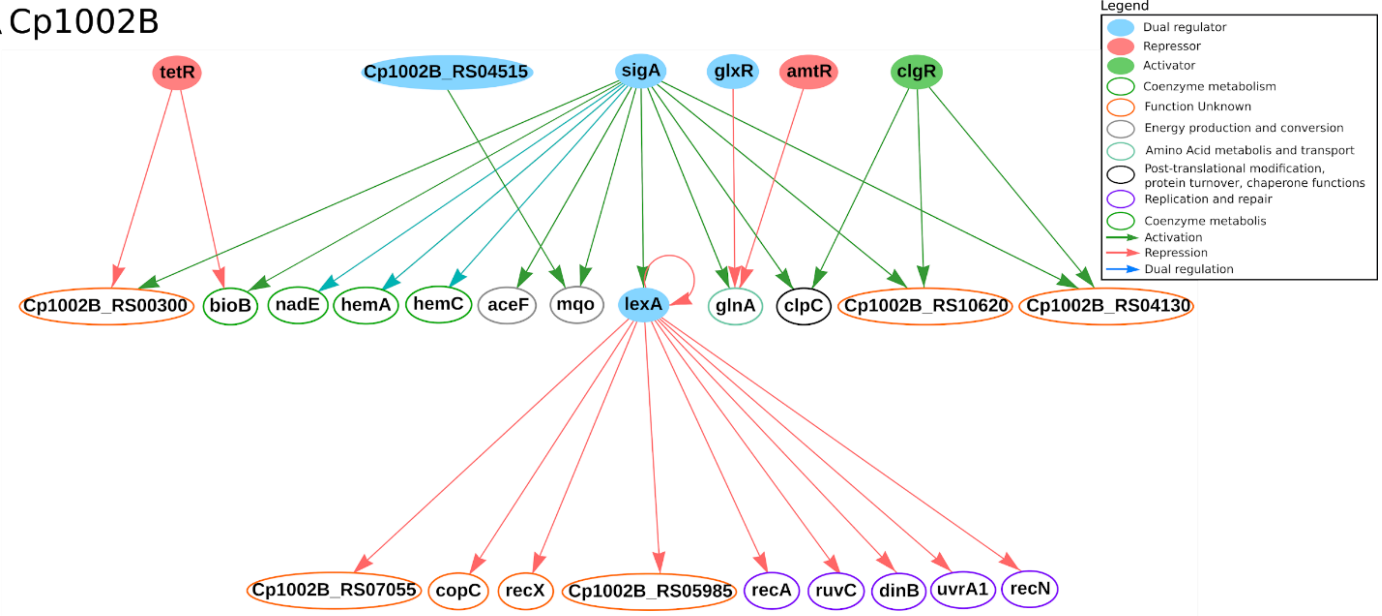

\section{B Cp258}
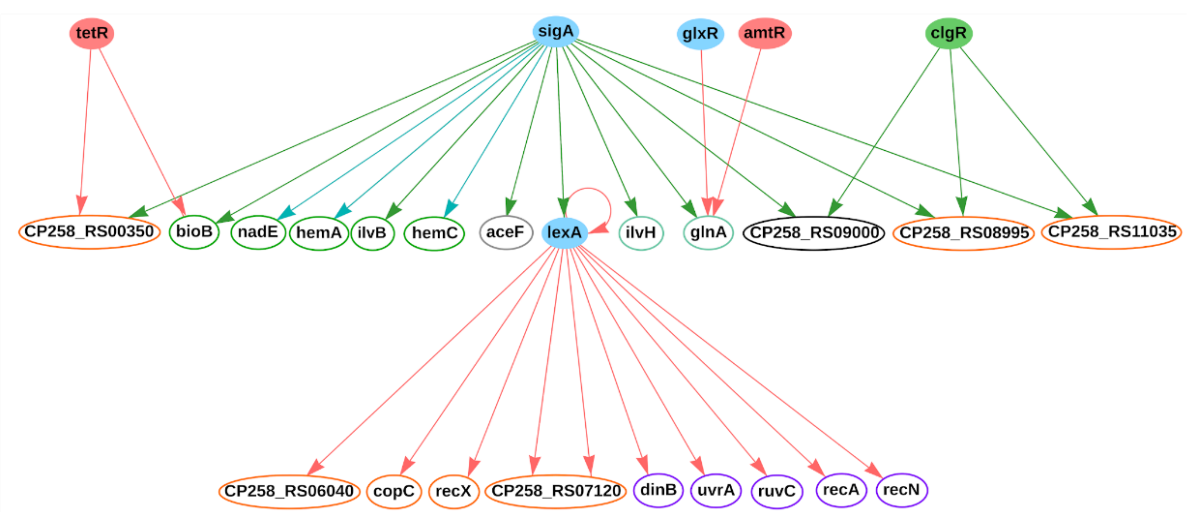

Figure 5. Regulatory interactions of SigA in C. pseudotuberculosis 1002B (A) and C. pseudotuberculosis 258 (B) from CoryneRegNet 7. In the network, nodes represent the genes and arrows represent the regulatory interactions. The functional classification was performed using the database Eggnog [90]. 


\section{Conclusions}

In this review, we presented the current knowledge of the landscape of C. pseudotuberculosis transcriptional regulation. The behavior of this organism under osmotic, acid, iron-starvation and thermal stress was studied exemplarily as well. We conclude that we have just begun to understand the importance of some key transcription factors, such as PhoP, DtxR, Rip $A$ and GlxR, as well as of some of the sigma factors. Apart from that, very little is known about the regulatory mechanisms of this organism. New RNA-seq analyses under several conditions and preferably also time-series data combined with other layers of regulatory data are still needed to unravel the pathogenicity, survival and adaptation of C. pseudotuberculosis in its diverse range of hosts. Such studies might contribute not only to correctly diagnosing and treating the diseases caused by this organism, but also to identifying better drugs and vaccine candidates based on regulatory pathomechanisms.

Author Contributions: Conceptualization, D.P., M.T.D.P., V.A.d.C.A. and J.B.; writing-original draft preparation, D.P., M.T.D.P. and A.C.P.G.; writing-review and editing, D.P., M.T.D.P., A.C.P.G., F.F.A., R.B.K., M.S.-A., A.T., V.A.d.C.A. and J.B.; supervision, J.B., V.A.d.C.A. and R.B.K.; All authors have read and agreed to the published version of the manuscript.

Funding: J.B. is grateful for support from H2020 grant RepoTrial (no. 777111) and his VILLUM Young Investigator grant (no. 13154). D.P. received support from CAPES (no. 88887.364607/2019-00) and M.T.D.P. from CNPq (no. 201336/2018-9), for their work at TUM in Germany. M.T.D.P.'s work was also supported by the German Research Foundation (under SFB924). V.A.C.A. is grateful for support from his CNPq Research Productivity grant (no. 305093/2015-0), CNPq Universal grant (no. 405233/2016-7) and FAPEMIG grant (no. APQ 02600-17). M.S.-A. received PhD fellowship funding from CONACYT (CVU659273) and the German Academic Exchange Service, DAAD (ref. 91693321). This study was financed in part by the Coordenação de Aperfeiçoamento de Pessoal de Nível Superior-Brasil (CAPES)-Finance Code 001.

Institutional Review Board Statement: Not applicable.

Informed Consent Statement: Not applicable.

Data Availability Statement: Data sharing not applicable.

Conflicts of Interest: The authors declare no conflict of interest.

\section{References}

1. González Plaza, J.J. Small RNAs as fundamental players in the transference of information during bacterial infectious diseases. Front. Mol. Biosci. 2020, 7, 101. [CrossRef]

2. Bervoets, I.; Charlier, D. Diversity, versatility and complexity of bacterial gene regulation mechanisms: Opportunities and drawbacks for applications in synthetic biology. FEMS Microbiol. Rev. 2019, 43, 304-339. [CrossRef]

3. Baumbach, J.; Brinkrolf, K.; Czaja, L.F.; Rahmann, S.; Tauch, A. CoryneRegNet: An ontology-based data warehouse of corynebacterial transcription factors and regulatory networks. BMC Genomics 2006, 7, 24. [CrossRef] [PubMed]

4. Babu, M.M.; Lang, B.; Aravind, L. Methods to reconstruct and compare transcriptional regulatory networks. Methods Mol. Biol. 2009, 541, 163-180.

5. Nagalakshmi, U.; Wang, Z.; Waern, K.; Shou, C.; Raha, D.; Gerstein, M.; Snyder, M. The transcriptional landscape of the yeast genome defined by RNA sequencing. Science 2008, 320, 1344-1349. [CrossRef] [PubMed]

6. Schena, M.; Shalon, D.; Davis, R.W.; Brown, P.O. Quantitative monitoring of gene expression patterns with a complementary DNA microarray. Science 1995, 270, 467-470. [CrossRef]

7. Hellman, L.M.; Fried, M.G. Electrophoretic mobility shift assay (EMSA) for detecting protein-Nucleic acid interactions. Nat. Protoc. 2007, 2, 1849-1861. [CrossRef]

8. Garner, M.M.; Revzin, A. The use of gel electrophoresis to detect and study nucleic acid—Protein interactions. Trends Biochem. Sci. 1986, 11, 395-396. [CrossRef]

9. Horak, C.E.; Snyder, M. ChIP-chip: A genomic approach for identifying transcription factor binding sites. Guide Yeast Genet. Mol. Cell Biol. Part B 2002, 350, 469-483.

10. Barski, A.; Cuddapah, S.; Cui, K.; Roh, T.-Y.; Schones, D.E.; Wang, Z.; Wei, G.; Chepelev, I.; Zhao, K. High-resolution profiling of histone methylations in the human genome. Cell 2007, 129, 823-837. [CrossRef]

11. Mantione, K.J.; Kream, R.M.; Kuzelova, H.; Ptacek, R.; Raboch, J.; Samuel, J.M.; Stefano, G.B. Comparing bioinformatic gene expression profiling methods: Microarray and RNA-Seq. Med. Sci. Monit. Basic Res. 2014, 20, 138-142. 
12. Hrdlickova, R.; Toloue, M.; Tian, B. RNA-Seq methods for transcriptome analysis. Wiley Interdiscip. Rev. RNA 2017,8 , e1364. [CrossRef] [PubMed]

13. Marguerat, S.; Bähler, J. RNA-seq: From technology to biology. Cell. Mol. Life Sci. 2010, 67, 569-579. [CrossRef] [PubMed]

14. Pan, W. A comparative review of statistical methods for discovering differentially expressed genes in replicated microarray experiments. Bioinformatics 2002, 18, 546-554. [CrossRef] [PubMed]

15. Dupuy, A.; Simon, R.M. Critical review of published microarray studies for cancer outcome and guidelines on statistical analysis and reporting. J. Natl. Cancer Inst. 2007, 99, 147-157. [CrossRef]

16. Furey, T.S. ChIP-seq and beyond: New and improved methodologies to detect and characterize protein-DNA interactions. Nat. Rev. Genetics 2012, 13, 840-852. [CrossRef]

17. Park, P.J. ChIP-seq: Advantages and challenges of a maturing technology. Nat. Rev. Genetics 2009, 10, 669-680. [CrossRef]

18. Buck, M.J.; Lieb, J.D. ChIP-chip: Considerations for the design, analysis, and application of genome-wide chromatin immunoprecipitation experiments. Genomics 2004, 83, 349-360. [CrossRef]

19. Santos-Zavaleta, A.; Salgado, H.; Gama-Castro, S.; Sánchez-Pérez, M.; Gómez-Romero, L.; Ledezma-Tejeida, D.; García-Sotelo, J.S.; Alquicira-Hernández, K.; Muñiz-Rascado, L.J.; Peña-Loredo, P.; et al. RegulonDB v 10.5: Tackling challenges to unify classic and high throughput knowledge of gene regulation in E. coli K-12. Nucleic Acids Res. 2019, 47, D212-D220. [CrossRef] [PubMed]

20. Zhu, B.; Stülke, J. SubtiWiki in 2018: From genes and proteins to functional network annotation of the model organism Bacillus subtilis. Nucleic Acids Res. 2018, 46, D743-D748. [CrossRef]

21. Ibarra-Arellano, M.A.; Campos-González, A.I.; Treviño-Quintanilla, L.G.; Tauch, A.; Freyre-González, J.A. Abasy Atlas: A comprehensive inventory of systems, global network properties and systems-level elements across bacteria. Database 2016, 2016. [CrossRef]

22. Parise, M.T.D.; Parise, D.; Kato, R.B.; Pauling, J.K.; Tauch, A.; de Azevedo, V.A.C.; Baumbach, J. CoryneRegNet 7, the reference database and analysis platform for corynebacterial gene regulatory networks. Sci. Data 2020, 7, 142. [CrossRef]

23. Kreikemeyer, B.; McIver, K.S.; Podbielski, A. Virulence factor regulation and regulatory networks in Streptococcus pyogenes and their impact on pathogen-Host interactions. Trends Microbiol. 2003, 11, 224-232. [CrossRef]

24. Pauling, J.; Röttger, R.; Neuner, A.; Salgado, H.; Collado-Vides, J.; Kalaghatgi, P.; Azevedo, V.; Tauch, A.; Pühler, A.; Baumbach, J. On the trail of EHEC/EAEC-Unraveling the gene regulatory networks of human pathogenic Escherichia coli bacteria. Integr. Biol. 2012, 4, 728-733. [CrossRef]

25. Galagan, J.E.; Minch, K.; Peterson, M.; Lyubetskaya, A.; Azizi, E.; Sweet, L.; Gomes, A.; Rustad, T.; Dolganov, G.; Glotova, I.; et al. The Mycobacterium tuberculosis regulatory network and hypoxia. Nature 2013, 499, 178-183. [CrossRef] [PubMed]

26. Gordon, B.R.G.; Li, Y.; Wang, L.; Sintsova, A.; van Bakel, H.; Tian, S.; Navarre, W.W.; Xia, B.; Liu, J. Lsr2 is a nucleoid-associated protein that targets AT-rich sequences and virulence genes in Mycobacterium tuberculosis. Proc. Natl. Acad. Sci. USA 2010, 107, 5154-5159. [CrossRef]

27. Gonzalo-Asensio, J.; Mostowy, S.; Harders-Westerveen, J.; Huygen, K.; Hernández-Pando, R.; Thole, J.; Behr, M.; Gicquel, B.; Martín, C. PhoP: A missing piece in the intricate puzzle of Mycobacterium tuberculosis virulence. PLoS ONE 2008, 3, e3496. [CrossRef] [PubMed]

28. Aguilar-Ayala, D.A.; Tilleman, L.; van Nieuwerburgh, F.; Deforce, D.; Palomino, J.C.; Vandamme, P.; Gonzalez-Y-Merchand, J.A.; Martin, A. The transcriptome of Mycobacterium tuberculosis in a lipid-rich dormancy model through RNAseq analysis. Sci. Rep. 2017, 7, 17665. [CrossRef]

29. Lee, J.; Lee, S.-G.; Kim, K.K.; Lim, Y.-J.; Choi, J.-A.; Cho, S.-N.; Park, C.; Song, C.-H. Characterisation of genes differentially expressed in macrophages by virulent and attenuated Mycobacterium tuberculosis through RNA-Seq analysis. Sci. Rep. 2019, 9, 4027. [CrossRef] [PubMed]

30. Huang, H.; Shao, X.; Xie, Y.; Wang, T.; Zhang, Y.; Wang, X.; Deng, X. An integrated genomic regulatory network of virulencerelated transcriptional factors in Pseudomonas aeruginosa. Nat. Commun. 2019, 10, 2931. [CrossRef] [PubMed]

31. Danielli, A.; Amore, G.; Scarlato, V. Built shallow to maintain homeostasis and persistent infection: Insight into the transcriptional regulatory network of the gastric human pathogen Helicobacter pylori. PLoS Pathog. 2010, 6, e1000938. [CrossRef] [PubMed]

32. Dorella, F.A.; Pacheco, L.G.C.; Oliveira, S.C.; Miyoshi, A.; Azevedo, V. Corynebacterium pseudotuberculosis: Microbiology, biochemical properties, pathogenesis and molecular studies of virulence. Vet. Res. 2006, 37, 201-218. [CrossRef]

33. Yeruham, I.; Friedman, S.; Perl, S.; Elad, D.; Berkovich, Y.; Kalgard, Y. A herd level analysis of a Corynebacterium pseudotuberculosis outbreak in a dairy cattle herd. Vet. Dermatol. 2004, 15, 315-320. [CrossRef]

34. Silva, A.; Schneider, M.P.C.; Cerdeira, L.; Barbosa, M.S.; Ramos, R.T.J.; Carneiro, A.R.; Santos, R.; Lima, M.; D’Afonseca, V.; Almeida, S.S.; et al. Complete genome sequence of Corynebacterium pseudotuberculosis I19, a strain isolated from a cow in Israel with Bovine Mastitis. J. Bacteriol. 2011, 193, 323-324. [CrossRef] [PubMed]

35. Spier, S.J.; Azevedo, V. Corynebacterium pseudotuberculosis infection in horses: Increasing frequency and spread to new regions of North America. Equine Vet. Educ. 2017, 29, 436-439. [CrossRef]

36. Selim, S.A. Oedematous skin disease of buffalo in Egypt. J. Vet. Med. B Infect. Dis. Vet. Public Health 2001, 48, 241-258. [CrossRef] [PubMed]

37. Windsor, P.A.; Bush, R.D. Caseous lymphadenitis: Present and near forgotten from persistent vaccination? Small Rumin. Res. 2016, 142, 6-10. [CrossRef] 
38. Brum, A.A.; de Rezende, A.F.S.; Brilhante, F.S.; Collares, T.; Begnine, K.; Seixas, F.K.; Collares, T.V.; Dellagostin, O.A.; Azevedo, V.; Santos, A.; et al. Recombinant esterase from Corynebacterium pseudotuberculosis in DNA and subunit recombinant vaccines partially protects mice against challenge. J. Med. Microbiol. 2017, 66, 635-642. [CrossRef] [PubMed]

39. Droppa-Almeida, D.; Franceschi, E.; Padilha, F.F. Immune-informatic analysis and design of peptide vaccine from multi-epitopes against Corynebacterium pseudotuberculosis. Bioinform. Biol. Insights 2018, 12, 117793221875533. [CrossRef]

40. Pinto, A.C.; de Sá, P.H.C.G.; Ramos, R.T.J.; Barbosa, S.; Barbosa, H.P.M.; Ribeiro, A.C.; Silva, W.M.; Rocha, F.S.; Santana, M.P.; de Paula Castro, T.L.; et al. Differential transcriptional profile of Corynebacterium pseudotuberculosis in response to abiotic stresses. BMC Genomics 2014, 15, 14. [CrossRef] [PubMed]

41. Gomide, A.C.P.; de Sá, P.G.; Cavalcante, A.L.Q.; de Jesus Sousa, T.; Gomes, L.G.R.; Ramos, R.T.J.; Azevedo, V.; Silva, A.; Folador, A.R.C. Heat shock stress: Profile of differential expression in Corynebacterium pseudotuberculosis biovar Equi. Gene 2018, 645, 124-130. [CrossRef]

42. Gomide, A.C.P.; Ibraim, I.C.; Alves, J.T.C.; de Sá, P.G.; de Oliveira Silva, Y.R.; Santana, M.P.; Silva, W.M.; Folador, E.L.; Mariano, D.C.B.; de Paula Castro, T.L.; et al. Transcriptome analysis of Corynebacterium pseudotuberculosis biovar Equi in two conditions of the environmental stress. Gene 2018, 677, 349-360. [CrossRef]

43. Ibraim, I.C.; Parise, M.T.D.; Parise, D.; Sfeir, M.Z.T.; de Paula Castro, T.L.; Wattam, A.R.; Ghosh, P.; Barh, D.; Souza, E.M.; Góes-Neto, A.; et al. Transcriptome profile of Corynebacterium pseudotuberculosis in response to iron limitation. BMC Genomics 2019, 20, 663. [CrossRef]

44. McKean, S.C.; Davies, J.K.; Moore, R.J. Expression of phospholipase D, the major virulence factor of Corynebacterium pseudotuberculosis, is regulated by multiple environmental factors and plays a role in macrophage death. Microbiology 2007, 153, $2203-2211$. [CrossRef] [PubMed]

45. Billington, S.J.; Esmay, P.A.; Glenn Songer, J.; Helen Jost, B. Identification and role in virulence of putative iron acquisition genes from Corynebacterium pseudotuberculosis. FEMS Microbiol. Lett. 2002, 208, 41-45. [CrossRef] [PubMed]

46. Tiwari, S.; da Costa, M.P.; Almeida, S.; Hassan, S.S.; Jamal, S.B.; Oliveira, A.; Folador, E.L.; Rocha, F.; de Abreu, V.A.C.; Dorella, F.; et al. C. pseudotuberculosis Phop confers virulence and may be targeted by natural compounds. Integr. Biol. 2014, 6, 1088-1099. [CrossRef] [PubMed]

47. Turkarslan, S.; Peterson, E.J.R.; Rustad, T.R.; Minch, K.J.; Reiss, D.J.; Morrison, R.; Ma, S.; Price, N.D.; Sherman, D.R.; Baliga, N.S. A comprehensive map of genome-wide gene regulation in Mycobacterium tuberculosis. Sci. Data 2015, 2, 150010. [CrossRef]

48. Luo, F.; Yang, Y.; Zhong, J.; Gao, H.; Khan, L.; Thompson, D.K.; Zhou, J. Constructing gene co-expression networks and predicting functions of unknown genes by random matrix theory. BMC Bioinform. 2007, 8, 299. [CrossRef]

49. Liu, W.; Li, L.; Long, X.; You, W.; Zhong, Y.; Wang, M.; Tao, H.; Lin, S.; He, H. Construction and Analysis of gene co-expression networks in Escherichia coli. Cells 2018, 7, 19. [CrossRef] [PubMed]

50. Brinkrolf, K.; Brune, I.; Tauch, A. The transcriptional regulatory network of the amino acid producer Corynebacterium glutamicum. J. Biotechnol. 2007, 129, 191-211. [CrossRef]

51. Kohl, T.A.; Tauch, A. The GlxR regulon of the amino acid producer Corynebacterium glutamicum: Detection of the corynebacterial core regulon and integration into the transcriptional regulatory network model. J. Biotechnol. 2009, 143, $239-246$. [CrossRef] [PubMed]

52. Balasubramanian, D.; Schneper, L.; Kumari, H.; Mathee, K. A dynamic and intricate regulatory network determines Pseudomonas aeruginosa virulence. Nucleic Acids Res. 2013, 41. [CrossRef] [PubMed]

53. Graham, M.R.; Smoot, L.M.; Migliaccio, C.A.L.; Virtaneva, K.; Sturdevant, D.E.; Porcella, S.F.; Federle, M.J.; Adams, G.J.; Scott, J.R.; Musser, J.M. Virulence control in group A Streptococcus by a two-component gene regulatory system: Global expression profiling and in vivo infection modeling. Proc. Natl. Acad. Sci. USA 2002, 99, 13855-13860. [CrossRef]

54. Franco, E.F.; Rana, P.; Queiroz Cavalcante, A.L.; da Silva, A.L.; Cybelle Pinto Gomide, A.; Carneiro Folador, A.R.; Azevedo, V.; Ghosh, P.; Ramos, R.T.J. Co-expression networks for causal gene identification based on RNA-Seq data of Corynebacterium pseudotuberculosis. Genes 2020, 11, 794. [CrossRef] [PubMed]

55. Nalluri, J.J.; Barh, D.; Azevedo, V.; Ghosh, P. miRsig: A consensus-based network inference methodology to identify pan-cancer miRNA-miRNA interaction signatures. Sci. Rep. 2017, 7, 39684. [CrossRef] [PubMed]

56. Nalluri, J.J.; Rana, P.; Barh, D.; Azevedo, V.; Dinh, T.N.; Vladimirov, V.; Ghosh, P. Determining causal miRNAs and their signaling cascade in diseases using an influence diffusion model. Sci. Rep. 2017, 7, 8133. [CrossRef]

57. Chen, W.-H.; Lu, G.; Chen, X.; Zhao, X.-M.; Bork, P. OGEE v2: An update of the online gene essentiality database with special focus on differentially essential genes in human cancer cell lines. Nucleic Acids Res. 2017, 45, D940-D944. [CrossRef]

58. Padilla, L.; Morbach, S.; Krämer, R.; Agosin, E. Impact of heterologous expression of Escherichia coli UDP-glucose pyrophosphorylase on trehalose and glycogen synthesis in Corynebacterium glutamicum. Appl. Environ. Microbiol. 2004, 70, 3845-3854. [CrossRef]

59. Anishetty, S.; Pulimi, M.; Pennathur, G. Potential drug targets in Mycobacterium tuberculosis through metabolic pathway analysis. Comput. Biol. Chem. 2005, 29, 368-378. [CrossRef]

60. Sharp, P.M.; Mitchell, K.J. Corynebacterium glutamicum arginyl-tRNA synthetase. Mol. Microbiol. 1993, 8, 200. [CrossRef] [PubMed]

61. de Bruin, O.M.; Duplantis, B.N.; Ludu, J.S.; Hare, R.F.; Nix, E.B.; Schmerk, C.L.; Robb, C.S.; Boraston, A.B.; Hueffer, K.; Nano, F.E. The biochemical properties of the Francisella pathogenicity island (FPI)-encoded proteins IglA, IglB, IglC, PdpB and DotU suggest roles in type VI secretion. Microbiology 2011, 157, 3483-3491. [CrossRef] [PubMed] 
62. Deng, C.; Lv, X.; Liu, Y.; Li, J.; Lu, W.; Du, G.; Liu, L. Metabolic engineering of Corynebacterium glutamicum S9114 based on wholegenome sequencing for efficient N-acetylglucosamine synthesis. Synth. Syst. Biotechnol. 2019, 4, 120-129. [CrossRef] [PubMed]

63. Boyle, D.S.; Donachie, W.D. mraY is an essential gene for cell growth in Escherichia coli. J. Bacteriol. 1998, 180, 6429-6432. [CrossRef]

64. Oguiza, J.A.; Malumbres, M.; Eriani, G.; Pisabarro, A.; Mateos, L.M.; Martin, F.; Martín, J.F. A gene encoding arginyl-tRNA synthetase is located in the upstream region of the lysA gene in Brevibacterium lactofermentum: Regulation of argS-lysA cluster expression by arginine. J. Bacteriol. 1993, 175, 7356-7362. [CrossRef] [PubMed]

65. Cracan, V.; Padovani, D.; Banerjee, R. IcmF is a fusion between the radical B12 enzyme isobutyryl-CoA mutase and its G-protein chaperone. J. Biol. Chem. 2010, 285, 655-666. [CrossRef] [PubMed]

66. Hayashi, M.; Mizoguchi, H.; Shiraishi, N.; Obayashi, M.; Nakagawa, S.; Imai, J.-I.; Watanabe, S.; Ota, T.; Ikeda, M. Transcriptome analysis of acetate metabolism in Corynebacterium glutamicum using a newly developed metabolic array. Biosci. Biotechnol. Biochem. 2002, 66, 1337-1344. [CrossRef]

67. Yang, Y.; Zhang, M.; Zhang, H.; Lei, J.; Jin, R.; Xu, S.; Bao, J.; Zhang, L.; Wang, H. Purification and characterization of Mycobacterium tuberculosis indole-3-glycerol phosphate synthase. Biochemistry 2006, 71, S38-S43. [CrossRef] [PubMed]

68. Peters-Wendisch, P.; Stolz, M.; Etterich, H.; Kennerknecht, N.; Sahm, H.; Eggeling, L. Metabolic engineering of Corynebacterium glutamicum for L-serine production. Appl. Environ. Microbiol. 2005, 71, 7139-7144. [CrossRef]

69. Lim, C.J.; Hwang, W.; Park, E.H.; Fuchs, J.A. Cyclic AMP-dependent expression of the Escherichia coli serC-aroA operon. Biochim. Biophys. Acta 1994, 1218, 250-253. [CrossRef]

70. Ikeda, M.; Wachi, M.; Jung, H.K.; Ishino, F.; Matsuhashi, M. The Escherichia coli mraY gene encoding UDP-N-acetylmuramoylpentapeptide: Undecaprenyl-phosphate phospho-N-acetylmuramoyl-pentapeptide transferase. J. Bacteriol. 1991, 173, 1021-1026. [CrossRef]

71. Burkovski, A. Cell envelope of corynebacteria: Structure and influence on pathogenicity. ISRN Microbiol. 2013, $2013,935736$. [CrossRef] [PubMed]

72. Chandrasekaran, S.; Price, N.D. Probabilistic integrative modeling of genome-scale metabolic and regulatory networks in Escherichia coli and Mycobacterium tuberculosis. Proc. Natl. Acad. Sci. USA 2010, 107, 17845-17850. [CrossRef]

73. Moraes, G.L.; Gomes, G.C.; de Monteiro Sousa, P.R.; Alves, C.N.; Govender, T.; Kruger, H.G.; Maguire, G.E.M.; Lamichhane, G.; Lameira, J. Structural and functional features of enzymes of Mycobacterium tuberculosis peptidoglycan biosynthesis as targets for drug development. Tuberculosis 2015, 95, 95-111. [CrossRef]

74. Altschul, S.F.; Madden, T.L.; Schäffer, A.A.; Zhang, J.; Zhang, Z.; Miller, W.; Lipman, D.J. Gapped BLAST and PSI-BLAST: A new generation of protein database search programs. Nucleic Acids Res. 1997, 25, 3389-3402. [CrossRef]

75. Wheeler, T.J.; Eddy, S.R. nhmmer: DNA homology search with profile HMMs. Bioinformatics 2013, 29 , 2487-2489. [CrossRef] [PubMed]

76. Pao, G.M.; Saier, M.H., Jr. Response regulators of bacterial signal transduction systems: Selective domain shuffling during evolution. J. Mol. Evol. 1995, 40, 136-154. [CrossRef]

77. Blanco, A.G.; Sola, M.; Gomis-Rüth, F.X.; Coll, M. Tandem DNA recognition by PhoB, a two-component signal transduction transcriptional activator. Structure 2002, 10, 701-713. [CrossRef]

78. Hoch, J.A. Two-component and phosphorelay signal transduction. Curr. Opin. Microbiol. 2000, 3, 165-170. [CrossRef]

79. López-Goñi, I.; Guzmán-Verri, C.; Manterola, L.; Sola-Landa, A.; Moriyón, I.; Moreno, E. Regulation of Brucella virulence by the two-component system BvrR/BvrS. Vet. Microbiol. 2002, 90, 329-339. [CrossRef]

80. Matsushita, M.; Janda, K.D. Histidine kinases as targets for new antimicrobial agents. Bioorg. Med. Chem. 2002, 10, 855-867. [CrossRef]

81. Cardona, P.J.; Asensio, J.G.; Arbués, A.; Otal, I.; Lafoz, C.; Gil, O.; Caceres, N.; Ausina, V.; Gicquel, B.; Martin, C. Extended safety studies of the attenuated live tuberculosis vaccine SO2 based on phoP mutant. Vaccine 2009, 27, 2499-2505. [CrossRef]

82. Capra, E.J.; Laub, M.T. Evolution of two-component signal transduction systems. Ann. Rev. Microbiol. 2012, 66, 325-347. [CrossRef]

83. Sorger-Herrmann, U.; Taniguchi, H.; Wendisch, V.F. Regulation of the pstSCAB operon in Corynebacterium glutamicum by the regulator of acetate metabolism RamB. BMC Microbiol. 2015, 15, 113. [CrossRef] [PubMed]

84. Söderberg, M.A.; Cianciotto, N.P. A Legionella pneumophila Peptidyl-Prolyl cis-trans Isomerase Present in Culture Supernatants is necessary for optimal growth at low temperatures. Appl. Environ. Microbiol. 2008, 74, 1634-1638. [CrossRef]

85. Göthel, S.F.; Scholz, C.; Schmid, F.X.; Marahiel, M.A. Cyclophilin and Trigger factor from Bacillus subtilis catalyze in Vitro protein folding and are necessary for viability under starvation conditionst. Biochemistry 1998, 37, 13392-13399. [CrossRef] [PubMed]

86. Unal, C.M.; Steinert, M. Microbial Peptidyl-Prolyl cis/trans Isomerases (PPIases): Virulence factors and potential alternative drug targets. Microbiol. Mol. Biol. Rev. 2014, 78, 544-571. [CrossRef] [PubMed]

87. Choi, S.; Choi, E.; Cho, Y.-J.; Nam, D.; Lee, J.; Lee, E.-J. The Salmonella virulence protein MgtC promotes phosphate uptake inside macrophages. Nat. Commun. 2019, 10. [CrossRef] [PubMed]

88. Eriksson, S.; Lucchini, S.; Thompson, A.; Rhen, M.; Hinton, J.C.D. Unravelling the biology of macrophage infection by gene expression profiling of intracellular Salmonella enterica. Mol. Microbiol. 2003, 47, 103-118. [CrossRef]

89. Heithoff, D.M.; Shimp, W.R.; House, J.K.; Xie, Y.; Weimer, B.C.; Sinsheimer, R.L.; Mahan, M.J. Intraspecies variation in the emergence of hyperinfectious bacterial strains in nature. PLoS Pathog. 2012, 8, e1002647. [CrossRef] 
90. Huerta-Cepas, J.; Szklarczyk, D.; Heller, D.; Hernández-Plaza, A.; Forslund, S.K.; Cook, H.; Mende, D.R.; Letunic, I.; Rattei, T.; Jensen, L.J.; et al. eggNOG 5.0: A hierarchical, functionally and phylogenetically annotated orthology resource based on 5090 organisms and 2502 viruses. Nucleic Acids Res. 2019, 47, D309-D314. [CrossRef]

91. Bibb, L.A.; Kunkle, C.A.; Schmitt, M.P. The ChrA-ChrS and HrrA-HrrS signal transduction systems are required for activation of the hmuO promoter and repression of the hemA promoter in Corynebacterium diphtheriae. Infect. Immun. 2007, 75, $2421-2431$. [CrossRef] [PubMed]

92. Frunzke, J.; Gätgens, C.; Brocker, M.; Bott, M. Control of heme homeostasis in Corynebacterium glutamicum by the two-component system HrrSA. J. Bacteriol. 2011, 193, 1212-1221. [CrossRef]

93. Keppel, M.; Hünnefeld, M.; Filipchyk, A.; Viets, U.; Davoudi, C.-F.; Krüger, A.; Mack, C.; Pfeifer, E.; Polen, T.; Baumgart, M.; et al. HrrSA orchestrates a systemic response to heme and determines prioritization of terminal cytochrome oxidase expression. Nucleic Acids Res. 2020, 48, 6547-6562. [CrossRef] [PubMed]

94. Browning, D.F.; Busby, S.J.W. The regulation of bacterial transcription initiation. Nat. Rev. Microbiol. 2004, 2, 57-65. [CrossRef]

95. Browning, D.F.; Butala, M.; Busby, S.J.W. Bacterial transcription factors: Regulation by pick “N” Mix. J Mol. Biol. 2019, 431, 4067-4077. [CrossRef]

96. Merchant, S.S.; Helmann, J.D. Elemental economy: Microbial strategies for optimizing growth in the face of nutrient limitation. Adv. Microb. Physiol. 2012, 60, 91-210.

97. Andrews, S.C.; Robinson, A.K.; Rodríguez-Quiñones, F. Bacterial iron homeostasis. FEMS Microbiol. Rev. 2003, 27, 215-237. [CrossRef]

98. Fu, M.; Su, H.; Su, Z.; Yin, Z.; Jin, J.; Wang, L.; Zhang, Q.; Xu, X. Transcriptome analysis of Corynebacterium pseudotuberculosisinfected spleen of dairy goats. Microb. Pathog. 2020, 147, 104370. [CrossRef]

99. Kunkle, C.A.; Schmitt, M.P. Analysis of a DtxR-regulated iron transport and siderophore biosynthesis gene cluster in Corynebacterium diphtheriae. J. Bacteriol. 2005, 187, 422-433. [CrossRef] [PubMed]

100. Trost, E.; Ott, L.; Schneider, J.; Schröder, J.; Jaenicke, S.; Goesmann, A.; Husemann, P.; Stoye, J.; Dorella, F.A.; Rocha, F.S.; et al. The complete genome sequence of Corynebacterium pseudotuberculosis FRC41 isolated from a 12-year-old girl with necrotizing lymphadenitis reveals insights into gene-regulatory networks contributing to virulence. BMC Genomics 2010, 11, 728. [CrossRef]

101. Dorella, F.A.; Estevam, E.M.; Pacheco, L.G.C.; Guimarães, C.T.; Lana, U.G.P.; Gomes, E.A.; Barsante, M.M.; Oliveira, S.C.; Meyer, R.; Miyoshi, A.; et al. In vivo insertional mutagenesis in Corynebacterium pseudotuberculosis: An efficient means to identify DNA sequences encoding exported proteins. Appl. Environ. Microbiol. 2006, 72, 7368-7372. [CrossRef]

102. Ribeiro, D.; de Rocha, F.S.; Leite, K.M.C.; de Soares, S.C.; Silva, A.; Portela, R.W.D.; Meyer, R.; Miyoshi, A.; Oliveira, S.C.; Azevedo, V.; et al. An iron-acquisition-deficient mutant of Corynebacterium pseudotuberculosis efficiently protects mice against challenge. Vet. Res. 2014, 45, 28. [CrossRef]

103. Henderson, A.G.; Ehre, C.; Button, B.; Abdullah, L.H.; Cai, L.-H.; Leigh, M.W.; DeMaria, G.C.; Matsui, H.; Donaldson, S.H.; Davis, C.W.; et al. Cystic fibrosis airway secretions exhibit mucin hyperconcentration and increased osmotic pressure. J. Clin. Invest. 2014, 124, 3047-3060. [CrossRef] [PubMed]

104. Wood, J.M. Bacterial responses to osmotic challenges. J. Gen. Physiol. 2015, 145, 381-388. [CrossRef]

105. Janakiraman, A.; Lesser, C.F. How to manage stress: Lessons from an intracellular pathogen. Virulence 2017, 8, 359-361. [CrossRef] [PubMed]

106. Fang, F.C.; Frawley, E.R.; Tapscott, T.; Vázquez-Torres, A. Bacterial stress responses during host infection. Cell Host Microbe 2016, 20, 133-143. [CrossRef] [PubMed]

107. Jozefczuk, S.; Klie, S.; Catchpole, G.; Szymanski, J.; Cuadros-Inostroza, A.; Steinhauser, D.; Selbig, J.; Willmitzer, L. Metabolomic and transcriptomic stress response of Escherichia coli. Mol. Syst. Biol. 2010, 6, 364. [CrossRef]

108. Ramos, J.L.; Martínez-Bueno, M.; Molina-Henares, A.J.; Terán, W.; Watanabe, K.; Zhang, X.; Gallegos, M.T.; Brennan, R.; Tobes, R. The TetR family of transcriptional repressors. Microbiol. Mol. Biol. Rev. 2005, 69, 326-356. [CrossRef] [PubMed]

109. McCarthy, R.R.; Mooij, M.J.; Reen, F.J.; Lesouhaitier, O.; O'Gara, F. A new regulator of pathogenicity (bvlR) is required for full virulence and tight microcolony formation in Pseudomonas aeruginosa. Microbiology 2014, 160, 1488-1500. [CrossRef]

110. Sasindran, S.J.; Saikolappan, S.; Dhandayuthapani, S. Methionine sulfoxide reductases and virulence of bacterial pathogens. Future Microbiol. 2007, 2, 619-630. [CrossRef]

111. Choi, S.H.; Baumler, D.J.; Kaspar, C.W. Contribution of dps to acid stress tolerance and oxidative stress tolerance in Escherichia coli O157: H7. Appl. Environ. Microbiol. 2000, 66, 3911-3916. [CrossRef]

112. Calhoun, L.N.; Kwon, Y.M. Structure, function and regulation of the DNA-binding protein Dps and its role in acid and oxidative stress resistance in Escherichia coli: A review. J. Appl. Microbiol. 2011, 110, 375-386. [CrossRef] [PubMed]

113. Das Gupta, T.; Bandyopadhyay, B.; Das Gupta, S.K. Modulation of DNA-binding activity of Mycobacterium tuberculosis HspR by chaperones. Microbiology 2008, 154, 484-490. [CrossRef] [PubMed]

114. Lindquist, S.; Craig, E.A. The heat-shock proteins. Ann. Rev. Genetics 1988, 22, 631-677. [CrossRef]

115. Bandyopadhyay, B.; Das Gupta, T.; Roy, D.; Das Gupta, S.K. DnaK dependence of the mycobacterial stress-responsive regulator HspR is mediated through its hydrophobic C-terminal tail. J. Bacteriol. 2012, 194, 4688-4697. [CrossRef]

116. Ishikawa, M.; Okamoto-Kainuma, A.; Matsui, K.; Takigishi, A.; Kaga, T.; Koizumi, Y. Cloning and characterization of clpB in Acetobacter pasteurianus NBRC 3283. J. Biosci. Bioeng. 2010, 110, 69-71. [CrossRef] [PubMed] 
117. Chastanet, A.; Derre, I.; Nair, S.; Msadek, T. clpB, a novel member of the Listeria monocytogenes CtsR regulon, is involved in virulence but not in general stress tolerance. J. Bacteriol. 2004, 186, 1165-1174. [CrossRef]

118. Engels, S.; Ludwig, C.; Schweitzer, J.-E.; Mack, C.; Bott, M.; Schaffer, S. The transcriptional activator ClgR controls transcription of genes involved in proteolysis and DNA repair in Corynebacterium glutamicum. Mol. Microbiol. $2005,57,576-591$. [CrossRef] [PubMed]

119. Doig, P.; Boriack-Sjodin, P.A.; Dumas, J.; Hu, J.; Itoh, K.; Johnson, K.; Kazmirski, S.; Kinoshita, T.; Kuroda, S.; Sato, T.-O.; et al. Rational design of inhibitors of the bacterial cell wall synthetic enzyme GlmU using virtual screening and lead-hopping. Bioorg. Med. Chem. 2014, 22, 6256-6269. [CrossRef]

120. Zhang, W.; Jones, V.C.; Scherman, M.S.; Mahapatra, S.; Crick, D.; Bhamidi, S.; Xin, Y.; McNeil, M.R.; Ma, Y. Expression, essentiality, and a microtiter plate assay for mycobacterial GlmU, the bifunctional glucosamine-1-phosphate acetyltransferase and N-acetylglucosamine-1-phosphate uridyltransferase. Int. J. Biochemistry Cell Biol. 2008, 40, 2560-2571. [CrossRef]

121. Kim, J.K.; Lee, H.J.; Kikuchi, Y.; Kitagawa, W.; Nikoh, N.; Fukatsu, T.; Lee, B.L. Bacterial cell wall synthesis gene uppP is required for Burkholderia colonization of the Stinkbug Gut. Appl. Environ. Microbiol. 2013, 79, 4879-4886. [CrossRef] [PubMed]

122. Zhao, H.; Sun, Y.; Peters, J.M.; Gross, C.A.; Garner, E.C.; Helmann, J.D. Depletion of undecaprenyl pyrophosphate phosphatases disrupts cell envelope biogenesis in Bacillus subtilis. J. Bacteriol. 2016, 198, 2925-2935. [CrossRef] [PubMed]

123. Braibant, M.; Guilloteau, L.; Zygmunt, M.S. Functional characterization of Brucella melitensis NorMI, an efflux pump belonging to the multidrug and toxic compound extrusion family. Antimicrob. Agents Chemother. 2002, 46, 3050-3053. [CrossRef]

124. Morita, Y.; Kodama, K.; Shiota, S.; Mine, T.; Kataoka, A.; Mizushima, T.; Tsuchiya, T. NorM, a putative multidrug efflux protein, of Vibrio parahaemolyticus and its homolog in Escherichia coli. Antimicrob. Agents Chemother. 1998, 42, 1778-1782. [CrossRef] [PubMed]

125. Spirig, T.; Weiner, E.M.; Clubb, R.T. Sortase enzymes in Gram-positive bacteria. Mol. Microbiol. 2011, 82, 1044-1059. [CrossRef]

126. Paterson, G.K.; Mitchell, T.J. The role of Streptococcus pneumoniae sortase A in colonisation and pathogenesis. Microbes Infect. 2006, 8, 145-153. [CrossRef]

127. Paget, M.S. Bacterial sigma factors and anti-sigma factors: Structure, function and distribution. Biomolecules 2015, 5, 1245-1265. [CrossRef]

128. Davis, M.C.; Kesthely, C.A.; Franklin, E.A.; MacLellan, S.R. The essential activities of the bacterial sigma factor. Can. J. Microbiol. 2017, 63, 89-99. [CrossRef]

129. Adcock, I.M.; Caramori, G. Transcription factors. Asthma COPD 2009, 373-380.

130. Feklístov, A.; Sharon, B.D.; Darst, S.A.; Gross, C.A. Bacterial sigma factors: A historical, structural, and genomic perspective. Annu. Rev. Microbiol. 2014, 68, 357-376. [CrossRef]

131. Kazmierczak, M.J.; Wiedmann, M.; Boor, K.J. Alternative sigma factors and their roles in bacterial virulence. Microbiol. Mol. Biol. Rev. 2005, 69, 527-543. [CrossRef] [PubMed]

132. Riordan, J.T.; Mitra, A. Regulation of Escherichia coli pathogenesis by alternative sigma factor N. EcoSal Plus $2017,7$. [CrossRef] [PubMed]

133. Pátek, M.; Nešvera, J. Sigma factors and promoters in Corynebacterium glutamicum. J. Biotechnol. 2011, 154, 101-113. [CrossRef] [PubMed]

134. Taniguchi, H.; Busche, T.; Patschkowski, T.; Niehaus, K.; Pátek, M.; Kalinowski, J.; Wendisch, V.F. Physiological roles of sigma factor SigD in Corynebacterium glutamicum. BMC Microbiol. 2017, 17, 158. [CrossRef]

135. Ruiz, J.C.; D’Afonseca, V.; Silva, A.; Ali, A.; Pinto, A.C.; Santos, A.R.; Rocha, A.A.M.C.; Lopes, D.O.; Dorella, F.A.; Pacheco, L.G.C.; et al. Evidence for reductive genome evolution and lateral acquisition of virulence functions in two Corynebacterium pseudotuberculosis strains. PLoS ONE 2011, 6, e18551. [CrossRef]

136. Helmann, J.D.; Chamberlin, M.J. Structure and function of bacterial sigma factors. Annu. Rev. Biochem. 1988, 57, 839-872. [CrossRef]

137. Wu, S.; Howard, S.T.; Lakey, D.L.; Kipnis, A.; Samten, B.; Safi, H.; Gruppo, V.; Wizel, B.; Shams, H.; Basaraba, R.J.; et al. The principal sigma factor sigA mediates enhanced growth of Mycobacterium tuberculosis in vivo. Mol. Microbiol. 2004, 51, 1551-1562. [CrossRef]

138. Rodriguez Ayala, F.; Bartolini, M.; Grau, R. The stress-responsive alternative sigma factor SigB of Bacillus subtilis and its relatives: An old friend with new functions. Front. Microbiol. 2020, 11, 228. [CrossRef]

139. Pacheco, L.; Castro, T.; Carvalho, R.; Moraes, P.; Dorella, F.; Carvalho, N.; Slade, S.; Scrivens, J.; Feelisch, M.; Meyer, R.; et al. A role for Sigma Factor $\sigma^{\mathrm{E}}$ in Corynebacterium pseudotuberculosis resistance to nitric oxide/peroxide stress. Front. Microbiol. 2012, 3, 126. [CrossRef] 